\title{
A SIMPLE PLAN FOR RAPIDLY AND SAFELY DRYING A SPECIFIC GRAVITY BOTTLE OR FLASK.
}

By J. SHEA, M.D.

IT not unfrequently occurs that a clean, $d r y$ sp. gr. bottle or flask is wanted for use, and in hurried drying sometimes get cracked. The following little device has been found useful :-

Wash the bottle or flask with distilled water and drain it for a moment or two. Then wash with a little strong alcohol and drain the bottle a second time. The alcohol need not be wasted, as it is but slighted diluted with the residual water from the first washing. When the bottle is again drained it remains wet with the diluted alcohol. Pour in a little dry ether and wash the bottle out with this. Again drain, and the warmth of the hand or very little extra heat will then completely dry the bottle or flask. The alcohol must of course be strong, and the ether dry, or the device fails. 